\title{
Early Selection of Douglas-Fir across South Central Coastal Oregon, USA
}

\author{
By C. A. Dean ${ }^{\left.1,{ }^{*}\right)}$ and R. W. StonecypheR ${ }^{2)}$
}

(Received $23^{\text {th }}$ December 2005)

\begin{abstract}
Details are given of three first-generation progeny tests (CB1, CB2 and CB3) of coastal Douglas-fir (Pseudotsuga menziesii [MIRB.] FRANCO var. menziesii) planted in the Coos Bay region of south-central coastal Oregon in 1973. The three tests included 15 polymix families based on a 10-pollen mix, and 27 families openpollinated on the ortet. The present study gives heritabilities and additive genetic correlations for growth measured between two and 17 years after planting. Correlated responses are estimated for volume at 17 years from early selection for height and diameter.

Between four and 17 years after planting the individual heritability $\left(h^{2}\right)$ of height of coastal Douglas-fir across the Coos Bay tests was quite stable between $\mathrm{h}^{2}=$ 0.18 and 0.22 . The heritability of stem diameter age-forage was consistently much lower than for height. In the critical age range for early selection between five and 10 years the individual heritability of diameter ranged from $\mathrm{h}^{2}=0.07$ to 0.10 .

The additive genetic correlations involving volume-17 and height or diameter increased to high values of $\mathrm{r}_{\mathrm{A}}=$ 0.80 to 0.84 between eight to 10 years after planting. Before seven years the absolute values of juvenilemature correlations were much lower.

The higher heritability of height made this trait the best criterion for early indirect selection to improve mature stem volume growth. Across these Coos Bay tests, early selection on stem height measured at 5-8 years after planting was estimated to produce almost $40 \%$ more gain per year in volume-17 compared with direct selection at 17 years on volume-17 itself. The recommendation for maximizing gain per year in mature volume of coastal Douglas-fir at Coos Bay is to select on height at 7-8 years when the mean height of trees in tests should be around 4.5 to 5.5 meters.
\end{abstract}

Key words: Douglas-fir, growth, heritability, juvenile-mature correlation, early selection efficiency.

\section{Introduction}

Most tree breeding programs are based on selection for traits measured on relatively juvenile trees with the objective of indirectly improving productivity of mature trees at rotation-end. Early selection on juvenile trees can reduce generation time (provided planning and management of the breeding program are good enough) and increase gain per year. Too early selection can give unacceptable reliability in terms of gains expected in mature performance.

\footnotetext{
1) Weyerhaeuser Company, PO Box 9777, Federal Way, WA 98063-9777 (USA).

2) Retired from Weyerhaeuser Company, Quantitative Forest Genetics Consulting, 116 NE Hillside Rd, Chehalis, WA 985322811 (USA).

*) Corresponding Author: christine.dean@weyerhaeuser.com
}

Reliable information on genetic parameters of potential early selection criteria, particularly juvenile-mature additive genetic correlations and changing heritabilities over time, are required to optimise the timing of early selection. MAGNUSSEN and YANCHUK (1988) urged breeders of coastal Douglas-fir to expand as quickly as possible the published literature on genetic parameters over time and other information that can help to make sure near-optimal selection age decisions are made across different regions and also different populations of the species.

Relatively few authors have addressed trends over time in genetic parameters and used these to attempt to predict optimal selection age of coastal Douglas-fir. STONECYPHER et al. (1996) suggested 8-15 years after planting as a reliable age-range for early selection of Douglas-fir for growth. JoHNson et al. (1997) reported rather broad age ranges for efficient early selection on growth of coastal Douglas-fir across a number of breeding regions in western Oregon; with the optimal age tending towards 8-10 years. The study of MAGNUSSEN and YANCHUK (1988) included a "bootstrap" modelling technique to generate probability distributions around juvenile - mature correlations and used these to give useful indications of risks of lower than expected genetic gain in mature performance. These authors found that for well replicated genetic tests (more than say 30 trees per family) early selection on growth of coastal Douglasfir in British Columbia is feasible at less than 10 years.

One important contribution of the modelling work done by MAGNUSSEN and YANCHUK (1988) is the strong connection made between quality of genetic field tests and reliability of early selection. ADAMs and JOYCE (1990) draw attention to the same issue. There will be differences in recommendations around optimum timing of selection across different field test qualities, site environment (JoHNSON et al., 1997) and provenances of Douglas-fir (Loo-Dinkins et al., 1991).

The objective of this study is to add to the available literature on juvenile - mature additive genetic correlations and changes in heritability of growth of coastal Douglas-fir (Pseudotsuga menziesii [MIRB.] FRANCO var. menziesii) until 17 years after planting across three sites in the Coos Bay region of south-central coastal Oregon, USA. Estimates are made of the optimum age for selecting Douglas-fir to improve stem volume at 17 years.

\section{Materials and Methods \\ Planting, Location and Environment}

The results reported here involve three genetic tests (identified as CB1, CB2 and CB3) that are part of Weyerhaeuser Company's first-generation coastal Douglasfir breeding (STONECYPHER et al., 1996). The tests are 
located in Weyerhaeuser plantations on the south-central Oregon coast (USA), between Coos Bay and Roseburg. The genetic tests were planted by hand in 1973 using containerised seedlings at 1,680 trees per hectare $(2.44 \times 2.44 \mathrm{~m})$. In 1984 (age 10-years) all tests were systematically thinned to approximately $50 \%$ of original stocking. This thinning removed smallest trees with the restrictions of maintaining approximately equal representation of families and uniform overall stocking across the site. Planting, site and environmental information about these three genetic tests are summarized in Table 1.

Table 1. - Site and design details of the Coos Bay genetic tests CB1, CB2 and CB3.

\begin{tabular}{lccc}
\hline Details & CB1 & CB2 & CB3 \\
\hline \hline & & & \\
Site Parameters & & & \\
Plantation name & $3291 \mathrm{Road}$ & $2176 \mathrm{Road}$ & $8225 \mathrm{Road}$ \\
Latitude & $43^{\circ} 30^{\prime} \mathrm{N}$ & $43^{\circ} 29^{\prime} \mathrm{N}$ & $43^{\circ} 19^{\prime} \mathrm{N}$ \\
Longitude & $123^{\circ} 47^{\prime} \mathrm{W}$ & $123^{\circ} 45^{\prime} \mathrm{W}$ & $123^{\circ} 40^{\prime} \mathrm{W}$ \\
Elevation (m) & 210 & 240 & 370 \\
Soil series & Hawkins & Doerne & Umpcoos \\
& & & \\
Field Design & & & 8 \\
Randomised blocks & 8 & 15 & 15 \\
Polymix families & 15 & 27 & 27 \\
Open-pollinated & 27 & & \\
\hline
\end{tabular}

Site quality across the three tests is reasonably similar with mean height growth of 13.7, 14.2 and $12.5 \mathrm{~m}$ to 17 years for CB1, CB2 and CB3. Test CB3 near Roseburg has the lowest site quality.

\section{Genetic Material}

Tests CB1, CB2 and CB3 involve 15 polymix and 27 open-pollinated first-generation families of coastal Douglas-fir; with three parents represented as both polymix and open-pollinated. The female parents of these families were selected in the mid-1960's from 60-80 year old natural stands below $600 \mathrm{~m}$ in the Coos Bay region; and judged to have grown under fully stocked conditions. The selection was on superior phenotype for stem diameter and branch retention within stand-plots of about 100 trees.

The polymix families were created from control-crossings carried out during 1971 in Weyerhaeuser's grafted seed orchard at Turner. The pollen mix used for the polymix crossings contained equal parts by weight of 10 first-generation Coos Bay parents ("self pollen" was excluded from the mix applied to particular female parents). Selection of parents used in the mix was based mainly on pollen availability. The 27 open-pollinated families were derived from seed collected on the ortets in native stands in Coos Bay.

\section{Field Design}

The three genetic tests are each based on eight randomized complete blocks and single-tree randomised non-contiguous plots; with families represented by four trees (single-tree plots) per block. Site variation was minimized by careful placement of blocks.

After the thinning of genetic tests in 1984, families were represented by average 16 trees per site. This number of offspring remains sufficient for reliable fieldtesting (COTTERILL and JAMES, 1984).

\section{Measurements}

Tests CB1-3 have been measured for stem height using a pole at ages two, three, four, five, six, seven, eight, 10 and 17 years after planting. Diameter overbark was measured with calipers at $50 \mathrm{~cm}$ at five, six, seven, eight and 10 years, and at breast-height $(1.37 \mathrm{~m})$ at 17 and 26 years. Stem volume was calculated from diameter and height for each tree using small-tree volume equations developed by BRUCE and DEMARs (1974).

\section{Statistical Analyses}

Analyses of Variance: The individual tree data of pooled half-sib (polymix and open-pollinated) families across tests CB1, CB2 and CB3 were analysed by SAS ${ }^{\circledR}$ PROC VARCOMP (Method = Type 1) using the following random effects model (SAS, 1990):

$$
\mathrm{P}_{\mathrm{ijkl}}=\mu+\mathrm{F}_{\mathrm{i}}+\mathrm{S}_{\mathrm{j}}+\mathrm{B}(\mathrm{S})_{\mathrm{jk}}+\mathrm{FS}_{\mathrm{ij}}+\mathrm{FB}(\mathrm{S})_{\mathrm{ijk}}+\mathrm{e}_{\mathrm{ijkl}}
$$

where $\mathrm{P}_{\mathrm{ijkl}}$ represents the phenotypic value of an individual tree for say height at 17 years, $F_{i}$ the effect of the half-sib (open-pollinated or polycross) family representing the ith female parent, $\mathrm{S}_{\mathrm{j}}$ the effect of the $\mathrm{j}$ th test site, $\mathrm{B}(\mathrm{S})_{\mathrm{jk}}$ the effect of the $\mathrm{k} t h$ block nested within the $\mathrm{j} t h$ test, $\mathrm{FS}_{\mathrm{ij}}$ and $\mathrm{FB}(\mathrm{S})_{\mathrm{ijk}}$ represent interactions, and $\mathrm{e}_{\mathrm{ijkl}}$ is the residual. Expectations of mean squares are given in Table 2. Any trees with height less than 2.5 standard deviations of the mean were omitted from the analyses. The trees remaining for analyses in CB1, CB2, and CB3 was very high at $88 \%, 97 \%$ and $91 \%$, respectively.

Genetic parameters were calculated separately for the polymix and open-pollinated families and the results proved quite consistent. Pooled values are used in this paper because they are more reliable due to the larger sample size.

Individual Heritabilities $\left(\mathrm{h}^{2}\right)$ : Were estimated as the ratio of additive genetic variance $\left(\sigma_{\mathrm{A}}^{2}\right)$ over the total phenotypic variance $\left(\sigma_{\mathrm{p}}^{2}\right)$ among individual trees across the three genetic tests:

$$
\begin{aligned}
& h^{2}=\sigma_{\mathrm{A}}^{2} /\left(\sigma_{\mathrm{P}}^{2}\right. \\
& =\left(3.3 \sigma_{\mathrm{f}}^{2}\right) /\left(\sigma_{\mathrm{f}}^{2}+\sigma_{\mathrm{fs}}^{2}+\sigma_{\mathrm{fs}(\mathrm{b})}^{2}+\sigma_{\mathrm{e}}^{2}\right)
\end{aligned}
$$

Table 2. - Expectations of mean squares for analyses of variance and covariance of half-sib (polymix and open-pollinated) families across genetic tests CB1, CB2 and CB3.

\begin{tabular}{lcl}
\hline Source of variation & d.f. ${ }^{\mathrm{A}}$ & \multicolumn{1}{l}{ Expectations of mean squares ${ }^{\mathrm{B}}$} \\
\hline Family & $(\mathrm{f}-1)$ & $\sigma_{\mathrm{e}}{ }^{2}+\mathrm{k}_{1} \sigma_{\mathrm{fb}(\mathrm{s})}{ }^{2}+\mathrm{k}_{4} \sigma_{\mathrm{fs}}{ }^{2}+\mathrm{k}_{6} \sigma_{\mathrm{f}}{ }^{2}$ \\
Family x test & $(\mathrm{f}-1)(\mathrm{s}-1)$ & $\sigma_{\mathrm{e}}{ }^{2}+\mathrm{k}_{2} \sigma_{\mathrm{fb}(\mathrm{s})}{ }^{2}+\mathrm{k}_{5} \sigma_{\mathrm{fs}}{ }^{2}$ \\
Family x block (test) & $\mathrm{s}(\mathrm{f}-1)(\mathrm{b}-1)$ & $\sigma_{\mathrm{e}}{ }^{2}+\mathrm{k}_{3} \sigma_{\mathrm{fb}(\mathrm{s})}{ }^{2}$ \\
Residual & $\mathrm{N}-\mathrm{fsb}$ & $\sigma_{\mathrm{e}}{ }^{2}$
\end{tabular}

A There are $f$ half-sib (polymix and open-pollinated) families, $s$ genetic tests, $b$ blocks nested within-tests, and $\mathrm{N}$ total trees analyzed for the combined data across tests CB1, CB2 and CB3.

${ }^{\mathrm{B}} \sigma^{2}{ }_{f}$ represents variance among half-sib (polycross and openpollinated) families, $\sigma_{\mathrm{fb}(\mathrm{s})}^{2}$ family x block-within-test interactions, $\sigma^{2}{ }_{\mathrm{fs}}$ family $\mathrm{x}$ test interactions and $\sigma^{2}$ the residual error. The $\mathrm{k}$ coefficients are estimated as harmonic means by the method of GOODNIGHT and SPEED (1978). 
where $\sigma_{f}^{2}$ represents the variance among the pooled half-sib families (polymix plus open-pollinated), $\sigma_{\mathrm{fs}}^{2}$ and $\sigma_{\mathrm{fb}(\mathrm{s})}^{2}$ variance due family $\mathrm{x}$ test and family $\mathrm{x}$ block-within-test interactions, respectively, and $\sigma^{2}$ is the residual variance. Note that in the above equation the family variance $\sigma^{2}$ is multiplied by 3.3 to estimate additive variance $\sigma^{2}{ }_{\mathrm{A}}$. The 3.3 multiplication factor assumes a coefficient of relationship (r) of $1 / 3$ among both the polymix and open-pollinated progeny; which is slightly higher than the true half-sib relationship $r=1 / 4$ (SQUILLACE, 1974; CAMPBELL, 1986). In fact the $\mathrm{r}$ coefficient will be marginally different for progeny of a 10-pollen mix compared with open-pollination on the ortet (SQUILLACE, 1974); but overall $\mathrm{r}=1 / 3$ seems reasonable for the purposes of this study.

Additive Genetic Correlations $\left(\mathrm{r}_{\mathrm{A}}\right)$ : Calculated as correlations among half-sib family means. The $r_{\mathrm{A}}$ were also calculated from variance and covariance's from analyses of pooled half-sib families using SAS ${ }^{\circledR}$ PROC CORR. The two sets of $r_{A}$ were found to be comparable, but the family mean $r_{\mathrm{A}}$ were used in this study because they were generally lower in magnitude (conservative in terms of early selection recommendations) and exhibited consistent trends over time.

\section{Efficiencies of Early Selection}

Direct Mature-Age Selection: Genetic gain $\Delta \mathrm{G}_{\mathrm{kk}}$ in the $\mathrm{k} t h$ trait (say stem volume at 17 years) as a result of one-generation of selection applied directly on that trait can be estimated as - (1):

$$
\Delta \mathrm{G}_{\mathrm{kk}} \text { per generation }=\mathrm{i} \mathrm{h}{ }_{\mathrm{k}}^{2} \sigma_{\mathrm{P} k}
$$

where $\mathrm{i}$ is the standardized selection intensity, $\mathrm{h}_{\mathrm{k}}^{2}$ the heritability of the $\mathrm{k} t h$ trait, and $\sigma_{\mathrm{P} k}$ the phenotypic standard deviation of the $\mathrm{k} t h$ trait.

Indirect Juvenile Selection: Correlated or indirect genetic gains $\Delta \mathrm{G}_{\mathrm{kn}}$ in the $\mathrm{k}$ th trait (volume-17) as a result of one-generation of selection applied on another trait, the $\mathrm{n} t h$ trait (say height at six years) can be estimated as - (2):

$$
\Delta \mathrm{G}_{\mathrm{kn}} \text { per generation }=\mathrm{i} \mathrm{r}_{\mathrm{A}} \mathrm{h}_{\mathrm{k}} \mathrm{h}_{\mathrm{n}} \sigma_{\mathrm{P} k}
$$

where $h_{k}$ and $h_{n}$ are the square roots of the individual heritabilities of the $\mathrm{k} t h$ and $\mathrm{n} t h$ traits, and $\mathrm{r}_{\mathrm{A}}$ the additive genetic correlation between the two traits. Equations (1) and (2) have been described by TURNER and Young (1969), LAMBETH (1980), FALCONER (1981), and others.

Efficiency of Indirect Selection: It is well known that efficiency $\left(Q_{\text {gen }}\right)$ of indirect selection can be calculated as the percentage ratio of gain per generation in the $\mathrm{k} t h$ trait from indirect selection on the $\mathrm{n} t h$ divided by gain in the $\mathrm{k} t h$ from direct selection on the $\mathrm{k} t h$ trait itself combining (1) and (2):

$$
\begin{aligned}
\mathrm{Q}_{\text {gen }} & =\Delta \mathrm{G}_{\mathrm{kn}} \text { per gen. } / \Delta \mathrm{G}_{\mathrm{kk}} \text { per gen. } \\
& =\left(\mathrm{r}_{\mathrm{A}} \mathrm{h}_{\mathrm{k}} \mathrm{h}_{\mathrm{n}} \sigma_{\mathrm{P} k} / \mathrm{h}^{2}{ }_{\mathrm{k}} \sigma_{\mathrm{P} k}\right) \times 100 \% \\
& =\left(\mathrm{r}_{\mathrm{A}} \mathrm{h}_{\mathrm{n}} / \mathrm{h}_{\mathrm{k}}\right) \times 100 \%
\end{aligned}
$$

Percent efficiency $\left(Q_{\text {year }}\right)$ can also be expressed in terms of relative genetic gains per year in the kth trait from indirect versus direct selection (TURNER and YouNG, 1969) -

$$
\mathrm{Q}_{\text {year }}=\Delta \mathrm{G}_{\mathrm{kn}} \text { per year } / \Delta \mathrm{G}_{\mathrm{kk}} \text { per year }
$$$$
=\left(\mathrm{r}_{\mathrm{A}} \mathrm{h}_{\mathrm{n}} / \mathrm{h}_{\mathrm{k}}\right) \times\left(\mathrm{l}_{\mathrm{k}} / \mathrm{l}_{\mathrm{n}}\right) \times 100 \%
$$

where $l_{n}$ represent the generation interval (in years) from indirect selection on the $\mathrm{n} t h$ trait and $\mathrm{l}_{\mathrm{k}}$ from direct selection on the kth trait. In the present study the generation interval for Douglas-fir breeding is calculated as the age of trees at selection plus six years for grafting and pollination to take place. For example, indirect selection on height at six years is assumed to involve a generation interval of $l_{n}=12$ years, and direct selection on volume at 17 years would involve a generation of $l_{k}=$ 23 years.

\section{Results and Discussion \\ Analyses of Variance}

Table 3 presents estimates of individual heritability $\left(h^{2}\right)$, additive genetic variance $\left(\sigma^{2}{ }_{A}\right)$, phenotypic variance $\left(\sigma_{\mathrm{p}}^{2}\right)$ and interaction variances for growth across the pooled half-sib progeny (polymix and open-pollinated) in the Coos Bay genetic tests CB1, CB2 and CB3. It is evident that family $\mathrm{x}$ test and family $\mathrm{x}$ block-within-test interactions accounted for very little variation in growth of coastal Douglas-fir across the three Coos Bay tests. Indeed, these interactions involving families were often estimated as negative components in the analyses of variance (in which case the $\sigma_{\mathrm{fs}}^{2}$ or $\sigma_{\mathrm{fb}(\mathrm{s})}^{2}$ were set at zero in Table 3). None of the interactions involving families were statistically significant at the $\mathrm{P}<0.05$ level. Although the results are not presented, it made little difference to the level of variance components whether the polymix and open-pollinated families were analyzed separately as two groups of families or as the data pooled.

\section{Individual Heritabilities}

Height: Stem height of half-sib coastal Douglas-fir progeny across the three Coos Bay tests had heritabilities between $h^{2}=0.10$ and 0.13 at two and three years after planting. At four years there was a quite marked increase in additive genetic variance $\left(\sigma_{A}^{2}\right)$ relative to phenotypic variance $\left(\sigma^{2}{ }_{\mathrm{P}}\right)$ and, hence, individual heritability increased to $\mathrm{h}^{2}=0.18$. Between four and 17 years the individual heritability of height stabilised at $\mathrm{h}^{2}=0.18$ to 0.22 ; mean of 0.20 . NAMKOONG et al. (1972) also found major changes in the variance structure of stem height with increasing age of Douglas-fir.

Following thinning at 10 years there was a substantial increase in the mean and variance of height across the three Coos Bay tests, but the heritability of height remained quite stable at $\mathrm{h}^{2}=0.21$ for height- 10 and 0.22 for height-17 (Table 3). The relative increase in both of $\sigma^{2}{ }_{\mathrm{A}}$ and $\sigma^{2}{ }_{\mathrm{P}}$ was about the same between 10 and 17 years, leading to this small change in heritability.

In a study of full-sib tests of coastal Douglas-fir grown at a range of close stockings in Washington State, CAMPBELL et al. (1986) observed similar individual heritabilities of height growth as those reported here. Values from the study of CAMPBELL et al. (1986) increased over time from $\mathrm{h}^{2}=0.13$ at five years to 0.21 at nine years. KING et al. (1988b) in two full-sib tests in British Columbia and ADAMs and JoYce (1990) in three open-pollinated tests 
Table 3. - Individual heritabilities $\left(\mathrm{h}^{2}\right)$ and variances associated with family $\mathrm{x}$ test $\left(\sigma_{\mathrm{fs}}^{2}\right)$, family x block-within-test $\left(\sigma_{\mathrm{fb}(\mathrm{s})}^{2}\right)$, additive genetic $\left(\sigma_{\mathrm{A}}^{2}\right)$ and overall phenotypic $\left(\sigma_{\mathrm{p}}^{2}\right)$ effects for height, diameter and stem volume of coastal Douglas-fir half-sib progeny (pooled polymix plus open-pollinated families) measured at different ages across genetic tests CB1, CB2 and CB3.

\begin{tabular}{|c|c|c|c|c|c|c|}
\hline \multirow{2}{*}{$\begin{array}{l}\text { Growth } \\
\text { trait }\end{array}$} & \multirow{2}{*}{$\begin{array}{c}\text { Mean } \\
\text { across } \\
\text { tests }\end{array}$} & \multicolumn{2}{|c|}{ Interaction variance } & \multirow{2}{*}{$\begin{array}{c}\text { Additive } \\
\text { genetic } \\
\text { variance } \\
\left(\sigma^{2}{ }_{A}\right)\end{array}$} & \multirow{2}{*}{$\begin{array}{c}\text { Phenotypic } \\
\text { variance } \\
\left(\sigma_{\mathrm{P}}^{2}\right)\end{array}$} & \multirow{2}{*}{$\begin{array}{c}\text { Individual } \\
\text { heritability } \\
\left(\mathrm{h}^{2}\right)\end{array}$} \\
\hline & & $\begin{array}{c}\text { Family } x \\
\text { site } \\
\left(\sigma_{\mathrm{fs}}^{2}\right)\end{array}$ & $\begin{array}{c}\text { Family } x \\
\text { block } \\
\left(\sigma_{\mathrm{fb}(\mathrm{s})}^{2}\right)\end{array}$ & & & \\
\hline
\end{tabular}

\begin{tabular}{|c|c|c|c|c|c|c|}
\hline \multicolumn{7}{|c|}{ Height (in meters) at Different Years after Planting: } \\
\hline Height- 2 & 0.59 & 0.0003 & 0.0002 & 0.002 & 0.018 & 0.10 \\
\hline Height-3 & 1.01 & 0.0005 & 0.0000 & 0.009 & 0.065 & 0.13 \\
\hline Height-4 & 1.63 & 0.0009 & 0.0000 & 0.030 & 0.169 & 0.18 \\
\hline Height-5 & 2.51 & 0.0017 & 0.0003 & 0.049 & 0.252 & 0.19 \\
\hline Height-6 & 3.49 & 0.0003 & 0.0000 & 0.082 & 0.375 & 0.22 \\
\hline Height-7 & 4.33 & 0.0029 & 0.0017 & 0.091 & 0.508 & 0.18 \\
\hline Height-8 & 5.30 & 0.0125 & 0.0112 & 0.128 & 0.710 & 0.18 \\
\hline Height- 10 & 7.21 & 0.0034 & 0.0116 & 0.210 & 1.008 & 0.21 \\
\hline Height-17 & 13.75 & 0.0089 & 0.0000 & 0.598 & 2.696 & 0.22 \\
\hline \multicolumn{7}{|c|}{ Diameter $(\mathrm{cm})$ at Years after Planting: } \\
\hline Dia-5 ${ }^{A}$ & 3.47 & 0.0000 & 0.0000 & 0.044 & 0.614 & 0.07 \\
\hline Dia-6 & 5.37 & 0.0099 & 0.0000 & 0.098 & 1.139 & 0.09 \\
\hline Dia-7 & 6.59 & 0.0034 & 0.0000 & 0.154 & 1.579 & 0.10 \\
\hline Dia-8 & 8.10 & 0.0161 & 0.0000 & 0.210 & 2.300 & 0.09 \\
\hline Dia-10 & 10.87 & 0.0262 & 0.0000 & 0.372 & 3.890 & 0.10 \\
\hline DBH-17 & 15.98 & 0.0000 & 0.0000 & 1.058 & 7.594 & 0.14 \\
\hline $\mathrm{DBH}-26$ & 22.83 & 0.0459 & 0.0000 & 2.652 & 18.33 & 0.14 \\
\hline \multicolumn{7}{|c|}{ Volume $\left(\mathrm{dm}^{3}\right)$ at Years after Planting: } \\
\hline Volume-5 & 1.80 & 0.0015 & 0.0000 & 0.053 & 0.487 & 0.11 \\
\hline Volume- 6 & 4.45 & 0.0074 & 0.0000 & 0.530 & 3.796 & 0.14 \\
\hline Volume-7 & 7.76 & 0.0000 & 0.0000 & 1.488 & 11.78 & 0.13 \\
\hline Volume- 8 & 13.63 & 0.2185 & 0.0000 & 4.425 & 35.26 & 0.13 \\
\hline Volume-10 & 31.99 & 0.6784 & 0.0000 & 24.443 & 184.27 & 0.13 \\
\hline Volume-17 & 124.7 & 0.0000 & 0.0000 & 385.24 & 2192.2 & 0.18 \\
\hline
\end{tabular}

Table 4. - Additive genetic juvenile-mature correlations between mature growth at 17 years and growth traits measured from two to 10 years for coastal Douglas-fir across genetic tests CB1, CB2 and CB3. The parameters have been calculated as correlations among the means of half-sib families.

\begin{tabular}{lcccc}
\hline & $\begin{array}{c}\text { Volume } \\
\text { 10 years }\end{array}$ & $\begin{array}{c}\text { Height } \\
17 \text { years }\end{array}$ & $\begin{array}{c}\text { Diameter } \\
17 \text { years }\end{array}$ & $\begin{array}{c}\text { Volume } \\
17 \text { years }\end{array}$ \\
\hline Height-2 & 0.40 & 0.47 & 0.30 & 0.37 \\
Height-3 & 0.61 & 0.67 & 0.42 & 0.54 \\
Height-4 & 0.63 & 0.68 & 0.42 & 0.54 \\
Height-5 & 0.72 & 0.77 & 0.52 & 0.64 \\
Height-6 & 0.72 & 0.79 & 0.50 & 0.64 \\
Height-7 & 0.79 & 0.86 & 0.67 & 0.78 \\
Height-8 & 0.77 & 0.87 & 0.75 & 0.84 \\
Height-10 & 0.79 & 0.93 & 0.69 & 0.82 \\
& & & & \\
Diameter-5 & 0.73 & 0.53 & 0.50 & 0.54 \\
Diameter-6 & 0.77 & 0.56 & 0.56 & 0.61 \\
Diameter-7 & 0.85 & 0.57 & 0.68 & 0.69 \\
Diameter-8 & 0.93 & 0.67 & 0.78 & 0.80 \\
Diameter-10 & 0.96 & 0.62 & 0.83 & 0.82 \\
& & & & \\
Volume-5 & 0.78 & 0.66 & 0.52 & 0.61 \\
Volume-6 & 0.80 & 0.67 & 0.55 & 0.64 \\
Volume-7 & 0.91 & 0.70 & 0.71 & 0.77 \\
Volume-8 & 0.96 & 0.79 & 0.82 & 0.88 \\
Volume-10 & 1.00 & 0.75 & 0.84 & 0.89 \\
\hline
\end{tabular}

in central-coastal Oregon reported marginally lower individual heritabilities of 0.12 to 0.14 for height of coastal Douglas-fir at 12-13 years. A trend of increasing heritability of growth over time was observed by JoHNson et al. (1997) across a broad range of sites in western
Oregon. Note that ADAMs and Joyce (1990) assumed a coefficient of relationship $r=1 / 3$ among open-pollinated progeny, while JoHnson et al. (1997) use $\mathrm{r}=1 / 4$.

Diameter and Volume: The heritability of stem diameter was consistently much lower age-for-age than the heritability of height of coastal Douglas-fir in the Coos Bay tests. Between five and 10 years after planting the individual heritability of diameter ranged from $\mathrm{h}^{2}=0.07$ to 0.10 (Table 3). Following thinning at 10 years the absolute magnitude of $\sigma_{\mathrm{A}}^{2}$ increased more than $\sigma_{\mathrm{P}}^{2}$, leading to an increase in heritability to $\mathrm{h}^{2}=0.14$ for both diameter-17 and diameter-26. It is known that the stocking rate can influence stem diameter more than height (Husch et al., 1972). ADAMS and JoyCE (1990) and KING et al. (1988b) also observed lower heritabilities for diameter growth compared with height of coastal Douglas-fir.

The heritability of stem volume followed the same general trend over time as the heritability of diameter (Table 3); due to the strong influence of diameter in the volume equation. However, the absolute values of the heritabilities of volume were a few points higher than those of diameter; reflecting the influence of height on volume. The individual heritabilities of volume of the half-sib coastal Douglas-fir progeny across the three Coos Bay tests proved to be very stable intermediate values of $\mathrm{h}^{2}=0.11$ to 0.14 between five and 10 years after planting; mean value 0.13 . The heritability of volume increase to $\mathrm{h}^{2}=0.18$ at 17 years (post-thinning). 
Table 5. - Additive genetic correlations between heights measured from two to 10 years for coastal Douglas-fir across genetic tests CB1, CB2 and CB3. The parameters have been calculated as correlations among half-sib family means.

\begin{tabular}{lcccccc}
\hline & $\begin{array}{c}\text { Height } \\
\text { 4 years }\end{array}$ & $\begin{array}{c}\text { Height } \\
\text { 5 years }\end{array}$ & $\begin{array}{c}\text { Height } \\
\text { 6 years }\end{array}$ & $\begin{array}{c}\text { Height } \\
\text { 7 years }\end{array}$ & $\begin{array}{c}\text { Height } \\
8 \text { years }\end{array}$ & $\begin{array}{c}\text { Height } \\
\text { 10 years }\end{array}$ \\
\hline \hline & & & & & & \\
Height-2 & 0.77 & 0.74 & 0.66 & 0.61 & 0.42 & 0.46 \\
Height-3 & 0.95 & 0.95 & 0.90 & 0.84 & 0.65 & 0.72 \\
Height-4 & & 0.98 & 0.95 & 0.85 & 0.63 & 0.72 \\
Height-5 & & & 0.98 & 0.92 & 0.74 & 0.81 \\
Height-6 & & & & 0.91 & 0.74 & 0.83 \\
Height-7 & & & & & 0.93 & 0.93 \\
Height-8 & & & & & & 0.94 \\
\hline
\end{tabular}

Table 6. - Additive genetic correlations between diameters measured from five to 10 years for coastal Douglas-fir across genetic tests CB1, CB2 and CB3. The parameters have been calculated as correlations among half-sib family means.

\begin{tabular}{lcccc}
\hline & $\begin{array}{c}\text { Diameter } \\
\text { 6 years }\end{array}$ & $\begin{array}{c}\text { Diameter } \\
\text { 7 years }\end{array}$ & $\begin{array}{c}\text { Diameter } \\
\text { 8 years }\end{array}$ & $\begin{array}{c}\text { Diameter } \\
\text { 10 years }\end{array}$ \\
\hline \hline & & & & \\
Diameter-5 & 0.91 & 0.87 & 0.85 & 0.73 \\
Diameter-6 & & 0.94 & 0.89 & 0.78 \\
Diameter-7 & & & 0.94 & 0.89 \\
Diameter-8 & & & & 0.95 \\
\hline
\end{tabular}

\section{Genetic Correlations}

Table 4 presents estimates of additive genetic correlations between "mature" volume-17 and "juvenile" height or diameter traits measured from two to 10 years after planting across the pooled half-sib progeny (polymix and open-pollinated) in tests CB1, CB2 and CB3. It is evident that from five to seven years the genetic correlations between height-5, -6 or -7 and volume-17 were stronger than corresponding correlations with juvenile diameter measured at the same age. For example, the genetic correlation between height- 7 and volume- 17 is $\mathrm{r}_{\mathrm{A}}$ $=0.78$ and the correlation between diameter- 7 and volume-17 is $\mathrm{r}_{\mathrm{A}}=0.69$ (Table 4). Tables 5 and 6 present additive genetic correlations between the "juvenile" height or diameter traits.

Juvenile-mature genetic correlations involving height or diameter and volume-17 increased to high values of $\mathrm{r}_{\mathrm{A}}=0.80$ to 0.84 between eight to 10 years after planting (Table 4). It is evident from Table 3 that the plantation age of 8-10 years corresponded to mean heights of trees between 5-7 $\mathrm{m}$ across the Coos Bay tests. In general the juvenile - mature additive genetic correlations presented

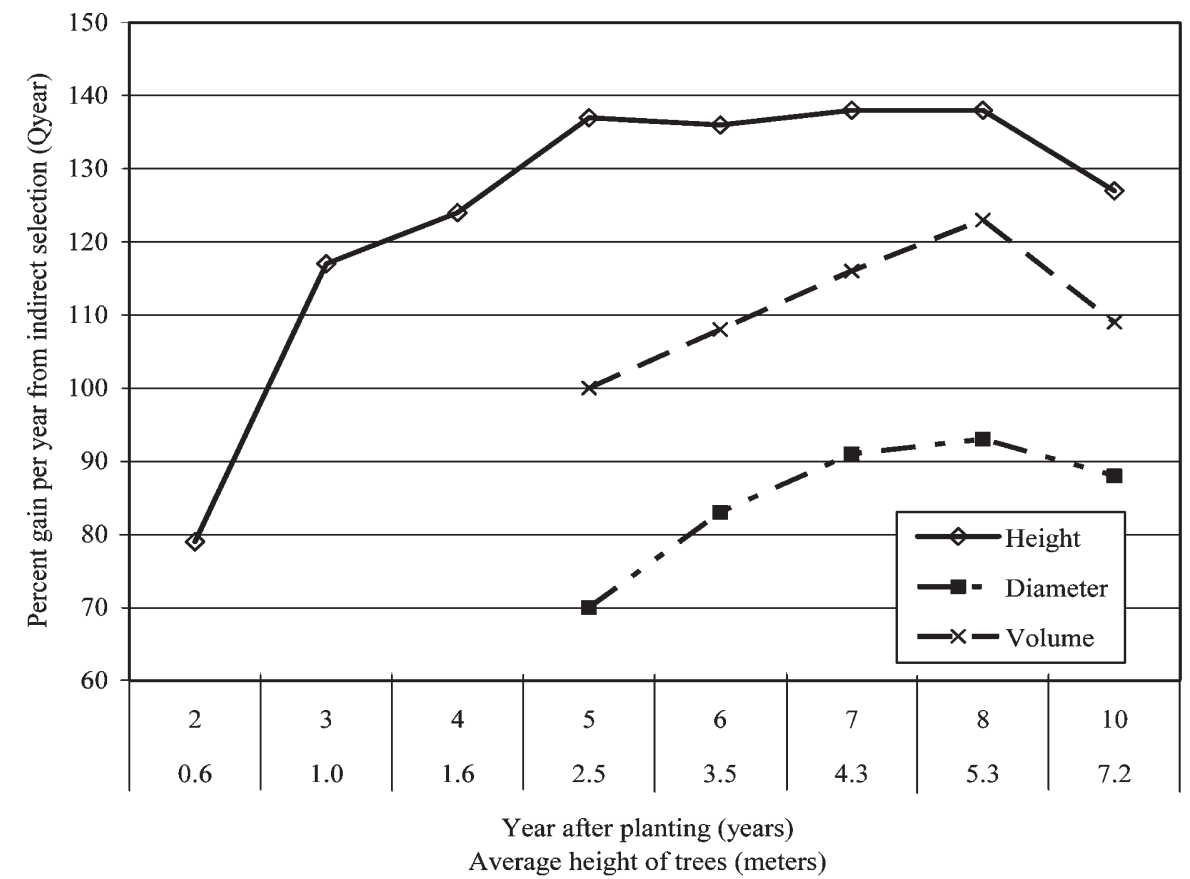

Figure 1. - Efficiencies $\left(\mathrm{Q}_{\text {year }}\right)$ of early selection on height, diameter or volume of coastal Douglas-fir across three genetic tests at Coos Bay. Efficiencies are in terms of indirect gains per year in volume measured at 17 years; with $\mathrm{Q}_{\text {year }}=100 \%$ indicating that early indirect selection will produce the same genetic gain per year in volume-17 compared with direct selection on volume-17 itself. Efficiencies of $\mathrm{Q}_{\mathrm{year}}>100 \%$ indicate that early selection will produce greater gains per year in volume-17. The generation interval for Douglas-fir breeding is calculated as the age of trees at selection plus six years for grafting and pollination to take place. 
here for the Coos Bay tests are of similar magnitude to means of estimates of JoHNSON et al. (1997) across a range of tests in western Oregon.

\section{Efficiencies of Early Selection}

Background: Figure 1 presents efficiencies $\left(\mathrm{Q}_{\text {year }}\right)$ of early selection on height, diameter or volume of coastal Douglas-fir at Coos Bay in terms of indirect gains per year in volume measured at 17 years. An efficiency of above $100 \%$ indicates that early indirect selection will produce greater genetic gain per year in volume-17 compared with direct selection on volume-17 itself. As mentioned previously, the generation interval used in these calculations is estimated as the age of trees at selection plus six years for grafting and pollination to take place.

Early Indirect Selection on Height: Figure 1 shows that height was clearly the best trait for early indirect selection to improve volume-17 of coastal Douglas-fir across the Coos Bay tests CB1, CB2 and CB3. Indirect selection on height-7 or height- 8 can be expected to produce $38 \%\left(\mathrm{Q}_{\text {year }}=138 \%\right.$; Figure 1$)$ more gain per year in volume-17 compared with direct selection at 17 years on volume-17 itself. The superiority of height for early selection is due to both its higher heritability than juvenile diameter (Table 3 ) and quite strong genetic correlations with volume-17 (Table 4).

In terms of timing of early selection on juvenile height there is an extended optimum period between 5-8 years after planting $\left(Q_{\text {vear }}=136-138 \%\right.$; Figure 1$)$. The magnitude and stability of additive genetic correlations between juvenile height and volume-17 favour the older aged end of this plateau in terms of minimising risk of inaccurate early selection. As mentioned previously, the additive genetic correlations between height- 7 or height8 and volume-17 are substantially higher $\left(\mathrm{r}_{\mathrm{A}}=0.78\right.$ to 0.84 ; Table 4) than those between height-5 or height- 6 and volume-17 $\left(\mathrm{r}_{\mathrm{A}}=0.64\right)$.

It is worth mentioning that early selection on growth at 7-8 years corresponds to a period when wood properties of Douglas-fir, such as specific gravity, should have stabilised sufficiently to allow reliable juvenile selection (KING et al., 1988a). In any case, selection strategies are available to permit juvenile selection at different times on different traits (such as growth and wood) without increasing generation time (e.g. ADAMS et al., 2001).

MAGNUSSEN and YANCHUK (1988) and JoHNSON et al. (1997) found broad "age-bands" for optimum or nearoptimum early selection of coastal Douglas-fir. In the case of MAGNUSSEN and YANCHUK (1988) the acceptable age-band for early family selection on growth in well replicated tests was 5-10 years (based on four progeny tests on Vancouver Island measured until 22 years). The optimum age-band across diverse tests studied by JoHNson et al. (1997) in Oregon tended to be a bit later at eight through 14 years, although the genetic tests assessed in this study tended to be slower growing.

Early Indirect Selection on Diameter or Volume: The optimum time for early selection on diameter or volume is eight years after planting (Figure 1). The maximum efficiency of early selection on diameter of coastal Douglas-fir across the Coos Bay tests never exceeded $\mathrm{Q}_{\text {year }}=$ $100 \%$ indicating that direct selection on volume-17 itself can be expected to produce greater gains per year than early indirect selection. The problem with early selection on diameter is the poor heritability of this trait.

Indirect selection on volume-8 produced $23 \%\left(\mathrm{Q}_{\text {year }}=\right.$ $123 \%$; Figure 1) more gain per year in volume-17 than later direct selection on volume-17 itself. The heritability of volume, and hence the gains from indirect selection, is intermediate between that of height and diameter.

\section{Conclusions}

Main conclusions and recommendations regarding trends over time in additive genetic parameters and early selection for growth of coastal Douglas-fir on good quality plantations in the Coos Bay region of south-central coastal Oregon are:

Genetic Parameters: Between four and 17 years after planting the individual heritability of height of coastal Douglas-fir across the Coos Bay tests was quite stable at between $\mathrm{h}^{2}=0.18$ and 0.22 . These heritabilities reflect significant amounts of additive genetic variation available for improvement of growth of Douglas-fir. The individual heritability of stem diameter age-for-age was consistently much lower than for stem height.

Additive genetic correlations involving volume-17 and height or diameter increased to quite high stable values of $r_{A}=0.80$ to 0.84 between 8-10 years. Before age- 7 the absolute values of juvenile-mature correlations were substantially lower.

Early Selection: The higher heritability of height made this trait the best criterion for early indirect selection to improve mature stem volume growth of coastal Douglas-fir across the Coos Bay tests. Early selection on stem height at 5-8 years gave $36-38 \%$ more gain per year in volume-17 compared with direct selection at 17 years. Early selection on diameter was far less efficient.

The recommendation from this present study is that gain per year in mature volume can be maximised by early selection on height at 7-8 years. At this age the mean height of trees in good quality field tests in central-coastal Oregon should be around 4.5 to 5.5 meters. The recommended 7-8 years is at the later end of a broader 5-8 years optimum selection band observed in this study; and should give more accurate early selection because of higher and more stable juvenile mature genetic correlations.

\section{Acknowledgements}

The following people made significant contributions to the Weyerhaeuser Douglas-Fir Tree Improvement Program during the establishment and measurement of the tests covered in this paper: Mike CARLson, Jess Daniels, Jim Dick, Gary Helland, Ed Herold, Liang Hsin, Lyle Linton, Rex McCullough, Dick Piesch, John Rediske, Jim Reno, George Staebler, Cheryl Talbert and Bill WeBb. We would also like to recognize Jim ClaRke, Tim KosDerka and Doug Soules who have been great operational supporters of Tree Improvement in Coos Bay region.

\section{Literature Cited}

Adams, W. T., S. N. Aitken, D. G. Joyce, G. T. Howe and J. VARGAS-HERnANDEZ (2001): Evaluating efficacy of 
early testing for stem growth in coastal Douglas-fir. Silvae Genet. 50: 167-175.

AdAMs, W. T. and D. G. Joyce (1990): Comparison of selection methods for improving volume growth in young coastal Douglas-fir. Silvae Genet. 39: 219-226.

BRuce, D. and D. J. Demars (1974): Volume equations for second-growth Douglas-fir. USDA, Forest Service Research Note PNW-239, USDA, PNWFRES: Portland, Oregon.

CAMPBELL, R. K. (1986): Mapped genetic variation of Douglas-fir to guide seed transfer in southwest Oregon. Silvae Genet. 35: 85-96.

CAmpbell, R. K., R. M. Echols and R. W. StonecypheR (1986): Genetic variances and interactions in 9-year Douglas-fir grown at narrow spacings. Silvae Genet. 35: 24-32.

CotTerill, P. P. and J. W. JAMEs (1984): Number of offspring and plot sizes required for progeny testing. Silvae Genet. 33: 203-209.

FALCONER, D. S. (1981): Introduction to Quantative Genetics. Second Edition. Longman Group, Essex, United Kingdom.

Goodnight, J. H. and F. M. Speed (1978): Computing expected mean squares. SAS Institute Technical Report R-102. SAS Institute Inc.: Cary, North Carolina.

Husch, B., C. I. Miller and T. W. Bears (1972): Forest Mensuation. John Wiley and Sons, New York.

Johnson, G. R., R. A. SNiEzko and N. L. MANDEL (1997): Age trends in Douglas-fir genetic parameters and implications for optimum selection age. Silvae Genet. 46: $349-358$.
King, J. N., F. C. YeH, J. C. H. Heaman and B. P. DANCIK (1988a): Selection of wood density and diameter in controlled crosses of coastal Douglas-fir. Silvae Genet. 37: 152-157.

King, J. N., F. C. YeH and J. C. H. Heaman (1988b): Selection of growth and yield traits in controlled crosses of coastal Douglas-fir. Silvae Genet. 37: 158-164.

LAMBETH, C. C. (1980): Juvenile-mature correlations in Pinaceae and implications for early selection. For. Sci. 26: $571-580$.

Loo-Dinkins, J. A., C. C. Ying and E. A. HAMM (1991): Stem volume and wood relative density of a non-local Douglas-fir provenance in British Columbia. Silvae Genet. 40: 29-35.

Magnussen, S. and A. D. YanchuK (1988): Selection age and risk: Finding the compromise. Silvae Genet. 42: $25-40$.

Namkoong, G., R. A. Usanis and R. R. Silen (1972): Agerelated variation in genetic control of height growth in Douglas-fir. Theor. and Appl. Genet. 42: 151-159.

SAS Institute Inc. (1990): User's guide. Cary, North Carolina: SAS Institute Inc.

Stonecypher, R. W., R. F. Piesch, G. G. Helland, J. G. CHAPMAN and H. J. RENO (1996): Results from genetic tests of selected parents of Douglas-fir (Pseudotsuga menziesii [MIRB.] FrANCO) in an applied tree improvement program. Forest Sci. Monograph 32: 1-35.

SQUILlaCE, A. E. (1974): Average genetic correlations among offspring from open-pollinated forest trees. Silvae Genet. 23: 149-156.

TuRNer, H. N. and S. S. Y. Young (1969): Quantitative Genetics in Sheep Breeding. Macmillan, Australia.

\title{
Bud Removal Affects Shoot, Root, and Callus Development of Hardwood Populus Cuttings
}

\author{
By A. H. Wiese ${ }^{1)}$, J. A. Zalesny ${ }^{2)}$, D. M. Donner ${ }^{1)}$ and R. S. ZAlesny JR. ${ }^{1)}{ }^{*}$ )
}

(Received 23 $3^{\text {rd }}$ December 2005)

\begin{abstract}
The inadvertent removal and/or damage of buds during processing and planting of hardwood poplar (Populus spp.) cuttings are a concern because of their potential impact on shoot and root development during establishment. The objective of the current study was to test for differences in shoot dry mass, root dry mass, number of roots, length of the longest root, and callus dry mass among ten poplar clones subjected to three pre-planting

\footnotetext{
1) USDA Forest Service, North Central Research Station, Forestry Sciences Laboratory, 5985 Highway K, Rhinelander, WI 54501, U.S.A.

2) Iowa State University, Department of Natural Resource Ecology and Management, 339 Science II, Ames, IA 50011, U.S.A.

*) Corresponding author (research plant geneticist); Phone: (715) 362-1132; Fax: (715) 362-1166; E-mail: rzalesny@ @fs.fed.us.
}

bud removal intensities $(0 \%, 50 \%, 100 \%)$. The ten clones and their genomic groups were: DM115 (P. deltoides Bartr. ex Marsh x P. maximowiczii A. Henry); DN34, I45-51 (P. deltoides x $P$. nigra L.); NC13446, NC13563, NC13649, NC13685, NC13747 [(P. trichocarpa Torr. \& Gray $\times$ P. deltoides) $\times$ P. deltoides]; and NM2, NM6 ( $P$. nigra $\times P$. maximowiczii). Cuttings, $20 \mathrm{~cm}$ long, were processed from shoots collected January 2005 from stool beds established at Hugo Sauer Nursery in Rhinelander, Wisconsin, U.S.A. $\left(45.6^{\circ} \mathrm{N}, 89.4^{\circ} \mathrm{W}\right)$. We measured the traits from harvested cuttings after $14 \mathrm{~d}$ of growth. The treatment $x$ clone interaction governed shoot dry mass $(P<0.0001)$. In general, the top four clones (DM115, DN34, NM2, NM6) exhibited the best shoot dry mass with $0 \%$ and $50 \%$ of buds removed, while differences among treatments for the remaining clones were negligible. Clones differed for root dry mass 